\title{
Burma or Myanmar? A Note on Terminology
}

In editing a collection such as this one, we are faced with the issue of what to call the country: Burma or Myanmar, or both? Using which criteria? This issue has long been contentious, and any discussion of the transition period must in some way address the concerns that continue to be raised about the country's name and how it should be historically referenced.

The country became the Union of Burma upon its independence from the British in 1948. Shortly following the massive and violently suppressed uprisings of 1988, the military regime, the State Law and Order Restoration Council (SLORC), enacted the 1989 Adaptation of Expressions Law, changing the name of the country to the Union of Myanmar and many place names to reflect their Burmese-language pronunciation rather than the anglicized spellings prescribed by British colonial authorities. Rangoon, for example, became Yangon. Although the SLORC argued that the switch to Myanmar was more inclusive of ethnic minority groups, the name change was met with stiff resistance by opposition activists pushing for democratic change, who argued that it was made by an illegitimate, unelected regime without the people's approval through a national referendum. Many of those who sympathized with the opposition felt the name Burma was more inclusive than Myanmar. As a result, the use of one name over the other was, and remains for some, an indication of one's political position with respect to the military regime (Rogers 2012). The reaction of ethnic minority groups in the country has been mixed, but many feel that both names lack a sense of inclusion because they refer to the country's dominant ethnic group (Dittmer 2014). 
International news outlets and governments around the world have taken different positions on this issue. The name change was recognized during military rule by the United Nations and by the governments of Japan and France, for example, but was not recognized by the United States, United Kingdom, Australia or Canada, which continued to refer to the country as Burma. The British Broadcasting Corporation (BBC) also referred to the country as Burma during the period of military rule, which they argued was due to the familiarity of the name rather than politically motivated (BBC 2007). The policy of the U.S. National Public Radio (NPR) network was to use Myanmar but to then reference the fact that the country was once called Burma (Memmott 2011). Even guidebooks have taken different positions. The Lonely Planet guidebook used the name Myanmar during military rule, while Rough Guides did not publish a guidebook out of support for the opposition movement's call for a tourism boycott (BBC 2007).

Academics and advocates have taken differing stances. Some authors use the two names interchangeably, some use Burma, some use Myanmar, and some choose to follow "the European Union's catch-all solution: 'Myanmar/Burma'" (Dittmer 2014, p. 2). Others have chosen to use Myanmar - as well as other changed place names - from 1989 onwards, while using Burma for the period when the country was called by that name (Cheesman, Skidmore and Wilson 2012). International human rights groups - like Human Rights Watch, the Burma Campaign UK and Altsean-Burma continue to use Burma. The participatory rights-based policy research and advocacy organization Progressive Voice notes that it generally uses Myanmar in acknowledgement of the fact that most people in the country use this term. It adds, however, that "the deception of inclusiveness and the historical process of coercion by the former State Peace and Development Council military regime into usage of 'Myanmar' rather than 'Burma' without the consent of the people is recognized and not forgotten. Thus, under certain circumstances, 'Burma' is used" (Progressive Voice 2018).

Inside the country, both terms are widely used, and several sources note that Myanmar is the more formal, literary term, while Burma is the term used more often in informal, everyday speech (BBC 2007). During the transition period starting in 2010, the name Myanmar has become much more common among those who may in the past have 
been unwilling or unsure which to use, and debate on this issue has cooled. Several non-governmental organizations and media outlets that were in exile or worked along the borders with Thailand and that used Burma in their titles have either changed their names in order to operate in the country or have registered themselves using their popular acronyms to get around the official requirement to use the name Myanmar. The names of cities, states and regions have also changed in many cases, both in casual conversations and written form; their names and their spelling can thus be inconsistent.

In Myanmar Media in Transition, we have chosen to use Myanmar for the period following the elections in 2010, and Burma for the period prior to this, except when replicating the usage in direct quotations or summaries of work by others. In these latter cases, we will remain consistent with the terminology used in the original work.

\section{References}

BBC. 2007. "Should it be Burma or Myanmar?" 2007. BBC News Magazine, 26 September 2007. http:// news.bbc.co.uk/2/hi/7013943.stm.

Cheesman, N., M. Skidmore, and T. Wilson, eds. 2012 Myanmar's Transition: Openings, Obstacles and Opportunities. Singapore: Institute of Southeast Asian Studies.

Dittmer, L., ed. 2014. Burma or Myanmar? The Struggle for National Identity. New Jersey: World Scientific.

Memmott, M. 2011. "Why Burma? Why Myanmar? Why Both?" National Public Radio, 2 December 2011. http://www.npr.org/sections/thetwoway/2011/12/02/143049567/ why-burma-why-myanmar-why-both.

Progressive Voice. 2018. "Repression by Any Means Necessary". https:// progressivevoicemyanmar.org/2018/09/19/repression-by-any-meansnecessary $/$.

Rogers, B. 2012. Burma: A Nation at the Crossroads. Rider Books. 
